\title{
Protective effects of coenzyme Q10 against sodium fluoride-induced reproductive disorders in male rats
}

\author{
S.M. Ali ${ }^{*}$, A.J. Nawfal ${ }^{2}$ and B.N. Al-Okaily ${ }^{1}$ \\ ${ }^{1}$ Department of Physiology, Biochemistry and Pharmacology, College of Veterinary Medicine, University of Baghdad, \\ Baghdad, ${ }^{2}$ Department of Physiology, College of Medicine, University of Al-Fallujah, Al-Fallujah, Iraq \\ Email: smmphy80@gmail.com
}

(Received May 22, 2018; Accepted September 1, 2018)

\begin{abstract}
This study was conducted to investigate the possible protective role of (CoQ10) on reproductive dysfunction of male rats induced by sodium fluoride $(\mathrm{NaF})$. thirty two rats were divided into four even groups and treated for 56 days as follows: the first group served as control (C) The second group (G1) received coenzyme Q10 at dose of $10 \mathrm{mg} / \mathrm{Kg} . \mathrm{B}$.W; while third group (G2) received 100ppmsodium fluoride in drinking water and fourth groups (G3) received NaF 100 ppm and CoQ10 10 $\mathrm{mg} / \mathrm{Kg}$.B.W for 56 days. The results showed that exposure of rats to NaF caused decrease in serum testosterone (T) and luteinizing hormones (LH) concentrations. Whereas Administration of CoQ10 caused an increase the concentrations of theses hormones in group G3 as compared with group G2. Testicular morphometric and histopathological alterations were observed in group G2 in the form of marked microvacuolation in the basal level of germinal cells, amyloid deposited within seminiferous tubules with disarrangement and depletion of germ cells. Whereas testicular histological alterations were improved in rats treated with CoQ10. In conclusion, the results of the present study showed that use of Co Q10 can alleviating the deleterious effects on male reproductive function following exposure to $\mathrm{NaF}$, may be via improvement the testicular functions or other related endocrine glands.
\end{abstract}

Keywords: Sodium fluoride, Coenzyme Q10, testosterone, LH, testicular morphometric, rats Available online at http://www.vetmedmosul.com

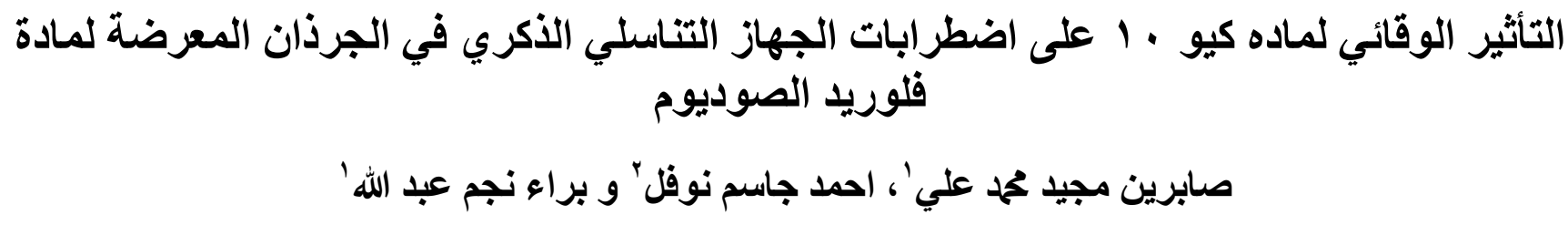

' فرع الفسلجة و الأدوية، كلية الطب البيطري، جامعة بغداد، بغداد، ‘ فرع الفسلجة، كلية الطب، جامعة الفلوجة، الفلوجة، العراق

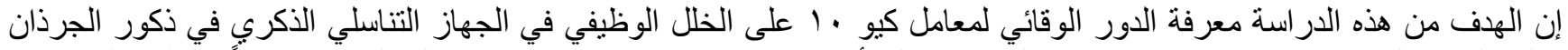

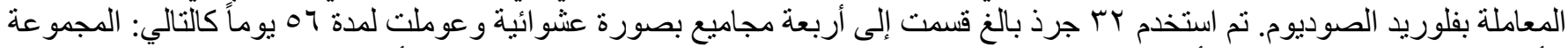

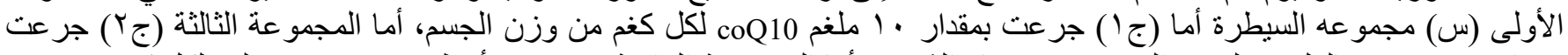

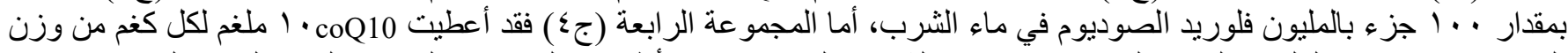

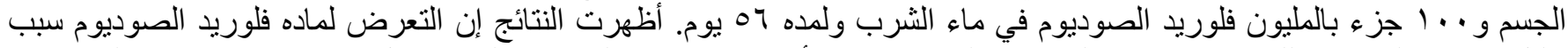

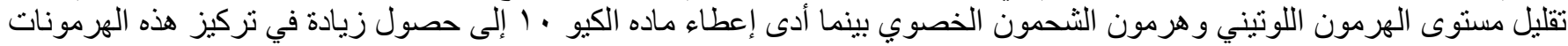

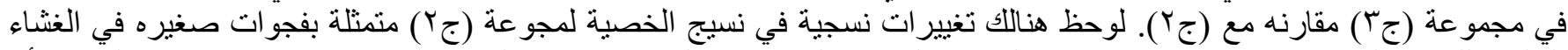

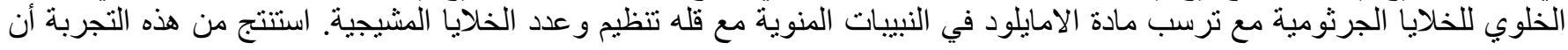




\section{استخدام كيو •ا أدى إلى تقليل التأثيرات الضارة لماده فلوريد الصوديوم على الجهاز التناسلي الذكري فضلا عن تقليل الإجهاد التأكسدي

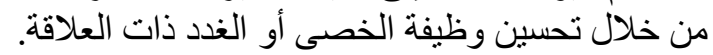

\section{Introduction}

Fluoride anions are present in ground water and drinking water and can be transported by fertilizers, volcanic activity and wind (1). Fluorine is used in aluminum production, fungicides, insecticides, pesticides, adhesives and glues (2,3). The compounds of fluoride are mostly used to keep from oral caries and to reduces the decay of teeth enamel (4). Furthermore (5) revealed that fluoride caused metabolic disturbance activities and lipid peroxidation (LPO) via inhibit certain antioxidant enzymes and reduce total serum protein (6-8) Involvement of the reproductive organs due to fluorosis in animals had also been studied extensively. Low levels of fluoride in food rendered mice infertile, while a high-fluoride diet improved their fertility (9). Other researchers concluded that treatment of mice with sodium fluoride caused an alteration in the histology of reproductive organs and morphology of sperm and induced biochemical changes (10). Besides demonstrates that fluoride hampers the reproductive functions of male rabbits and is proportional to the duration of fluoride exposure. Coenzyme Q10foundwith highest concentrations in heart, liver, kidney, pancreas and brain with the lowest concentration in the lungs (11). CoQ10 considered as the third most sold dietary supplement in the United States after omega-3 fatty acids and multivitamins).It is a unique lipid soluble vitamin-like substance synthesized endogenously (12) and play unique role in mitochondrial bioenergetics in the electron transport chain (ETC) as an electron carrier from enzyme complex I and enzyme complex II to complex III, thereby, it is appear to play an important role in formation of ATP and energy metabolism $(13,14)$, since no other molecule can perform this function.

Mutations in the genes involved in the biosynthesis of CoQ10 causing disruption of mitochondrial bioenergetics and induced oxidative stress $(15,16)$ which related to induced different diseases. Coenzyme Q10 is an antioxidant molecule, therefore, exogenous supplementation of coenzyme Q10 caused improvement the bioenergetics impairment in some mitochondrial myopathies, cardiomyopathy $(17,18)$ and counteracting some of tissue damage induced by free radicals such as nephrotoxicity, inflammation and apoptosis (19-21) and liver injury $(22,23)$ via its cytoprotective and antioxidant properties (24-26). In vivo, the exogenous administration of CoQ10 increases both ubiquinone and ubiquinol levels in semen and can be effective in improving sperm kinetic features in idiopathy patients affected by as well as, CoQ10 improve sperm parameters (27-28). CoQ10 can attenuate oxidative stress in seminal plasma and improve antioxidant enzymes activity (29). Therefore, the present study was aimed to evaluate the role of CoQ10 in ameliorating testicular dysfunctions of rats exposed to sodium fluoride in drinking water.

\section{Materials and methods}

This study has been conducted on 32 adults male Wistar albino rats It aged 3 months and weighted $200 \pm 10 \mathrm{~g}$. They were adopted in the animal house of College of Veterinary Medicine University of Baghdad. They were housed in a well-ventilated rooms inside plastic cages and feed on standard pellet diet and drinking water ad libitum during the experiment. The room temperature was $23 \pm 2^{\circ} \mathrm{C}$ for $12 \mathrm{hrs}$. light/dark cycle along the experimental period. Thirty two adult rats were selected randomly and divided into four equal groups ( 8 rats /group)and were handled daily as follows for 55 days: group $\mathrm{C}$ : rats in this group rats were received ordinary tap water plus intubated Dimethylsulfoxid (DMSO) 1\% and served as control; group G1 were intubated CoQ10 at dose of $10 \mathrm{mg} / \mathrm{kg} \mathrm{B.W}$. only (by dissolved in 1\% DMSO); group G2: rats were administered sodium fluoride (SF) in tap water $100 \mathrm{ppm}$ and group G3 were intubated daily CoQ10 at dose of $10 \mathrm{mg} / \mathrm{kg} \mathrm{BW}$ plus received ordinary tap water containing SF 100 ppm.

Blood samples were collected at day zero and at end of experiment, blood was drawn by retro-orbital Sinus technique according to (30) from anesthetized rats by intramuscular injection of Ketamine $90 \mathrm{mg} / \mathrm{kg} \mathrm{B.W}$. and Xylazine 40mg/kg B.W. using Micro-Hematocrit capillary tubes. Serum were gained by centrifugation for 15 minutes at $3000 \mathrm{rpm}$ and kept tightly stopper tubes frozen for next chemical analysis at $-20{ }^{\circ} \mathrm{C}$. Testosterone (T) and luteinizing hormones ( $\mathrm{LH})$ concentrations were estimated by an enzyme-linked immune sorbent assay (ELISA) method using a commercial kit (Elabscience Biotechnology Co. ltd, China).

At the end of the experiment testicular tissues were excised, cleared and immediately fixed in $10 \%$ formaldehyde in buffered solution containing 54 $\mathrm{mMNaH}_{2} \mathrm{PO}_{4}$ and 28 mMNa2HPO4 (pH 7.4). Then formaldehyde-fixed sample were embedded in paraffin and sliced with thickness of 5-6 micrometer and stained with Hematoxylin-Eosin stain (H\&E) using standard histological methods according to (31). Data have been analyzed statistically using the Microsoft Program of Statistical Package for the Social Science (SPSS) version 20. Statistical analysis of data was conducted on the basis of Two-Way Analysis of Variance (ANOVA) utilizing a 
significant level of $(\mathrm{P}<0.05)$. Specific group differences were determined using Least Significant Differences (LSD) as portrayed by (32).

\section{Results}

Along experimental period a significant decrease $(\mathrm{P}<0.05)$ in serum testosterone concentration was observed in group G2 $0.79 \pm 0.05$ after receiving $\mathrm{NaF}$ in drinking water comparing to the values in control, G1 and G3 groups with mean values were $1.30 \pm 0.02,1.48 \pm 0.10$ and $1.12 \pm 0.0$ respectively. Highest significant $(\mathrm{P}<0.05)$ increase in testosterone hormone level was observed in group G1 at the end of the experiment $1.48 \pm 0.10$ comparing to the value in other treated groups (Table 1). The results also showed a significant $(\mathrm{P}<0.05)$ increase in serum testosterone concentration in groups $\mathrm{G} 3$ comparing to the value in $\mathrm{NaF}$ treated group (G2) group at the end of the experiment. With exception to the value in G1 which showed significant increase $(\mathrm{P}<0.05)$ in testosterone hormone concentration, within the time, a significant $(\mathrm{P}<0.05)$ decrease was observed in G2 and G3 groups along experimental period comparing to zero time.

Table 2 demonstrated that $\mathrm{NaF}$ caused significant $(\mathrm{P}<0.05)$ decrease in serum LH concentration in groups $\mathrm{G} 2$ along the experimental period $1.36 \pm 0.12$ comparing to the values in other experimental groups. The values were $2.34 \pm 0.14,2.26 \pm 0.15$ and $1.94 \pm 0.11$ for control, G1 and G3 groups respectively within the time, non- significant $(\mathrm{P}>0.05)$ differences were observed in control, G1 and G3 groups along experimental period comparing to zero time.

The mean value of seminiferous tubules diameter and high of germinal epithelial cells of tubules in testes of were illustrated in table 3 . The histological sections of rat testes received 100ppm of $\mathrm{NaF}$ in drinking water (Group G2) exhibited a significant $(\mathrm{P}<0.05)$ decrease in high of epithelial cells and diameter of seminiferous tubules as compared to control and G1 groups. While in $\mathrm{NaF}+\mathrm{CoQ} 10$ (G3) treated group there were non- significant $(\mathrm{P}>0.05)$ remarkable elevation in high of germ cells and diameter of tubules compared to G2. Moreover, the value of G3tend to normalize that of the control. On the other hand, there was no significant $(\mathrm{P}>0.05)$ differences observed between group $\mathrm{G} 1$ and control as compared to each other.

Table 1: Effect of CoQ10 on testosterone hormone concentration in sodium fluoride treated adult rats

\begin{tabular}{lcccc}
\hline \multirow{2}{*}{ Time } & \multicolumn{4}{c}{ testosterone hormone concentration $(\mathrm{ng} / \mathrm{ml})$} \\
\cline { 2 - 5 } & control & $\mathrm{G} 1$ & $\mathrm{G} 2$ & $\mathrm{G} 3$ \\
\hline \multirow{2}{*}{ Zero } & $1.35 \pm 0.02$ & $1.28 \pm 0.03$ & $1.32 \pm 0.02$ & $1.30 \pm 0.02$ \\
& $\mathrm{~A} \mathrm{a}$ & $\mathrm{A} \mathrm{b}$ & $\mathrm{A} \mathrm{b}$ & $\mathrm{A} \mathrm{a}$ \\
\multirow{2}{*}{56 day } & $1.30 \pm 0.02$ & $1.48 \pm 0.10$ & $0.79 \pm 0.05$ & $1.12 \pm 0.10$ \\
& $\mathrm{~B} \mathrm{a}$ & $\mathrm{A} \mathrm{a}$ & $\mathrm{C} \mathrm{a}$ & $\mathrm{B} \mathrm{b}$ \\
\hline
\end{tabular}

Values are represented as mean \pm SE. $n=8$. Different small letters denote the presence of significant differences $(\mathrm{P} \leq 0.05)$ between periods. Different capital letters denote the presence of significant differences $(\mathrm{P} \leq 0.05)$ between groups control: rats received tap water; $\mathrm{G} 1$ : received 10 $\mathrm{mg} / \mathrm{kg}$ B.W. of CoQ10 orally; G2 received tap water contain NaF100 ppm and G3: received tap water contain $\mathrm{NaF} 100 \mathrm{ppm}$ Plus $10 \mathrm{mg} / \mathrm{kg}$ B.W. of CoQ10.

Table 2: Effect of CoQ10 on testosterone and luteinizing hormone concentration in sodium fluoride treated adult rats

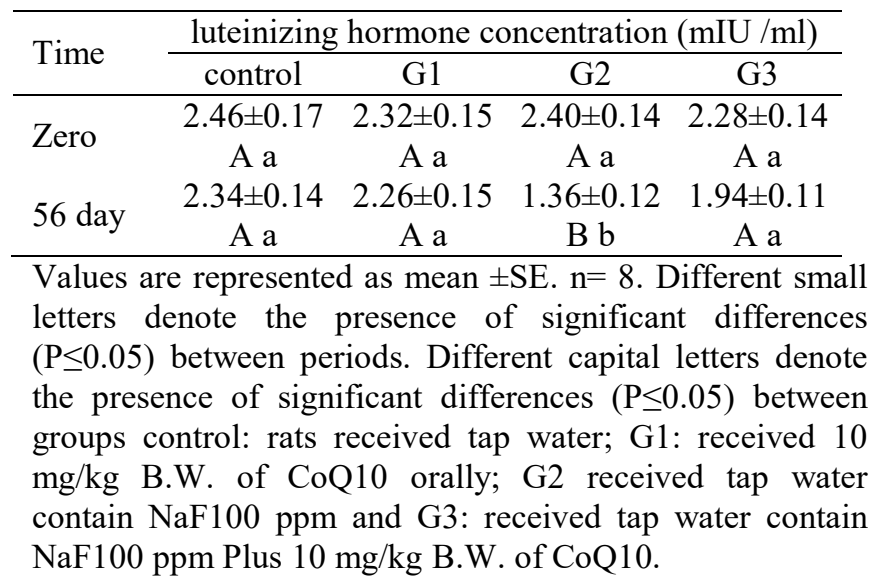

Table 3: Effect of CoQ10 on Diameter of seminiferous tubules diameter and high of germinal epithelial cells of tubules in sodium fluoride treated adult rats

\begin{tabular}{lcccc}
\hline \multirow{2}{*}{ Parameters } & \multicolumn{4}{c}{ Groups } \\
\cline { 2 - 5 } & control & G1 & G2 & G3 \\
\hline Diameter of seminiferous tubules $(\mu \mathrm{m})$ & $166.18 \pm 4.32 \mathrm{ab}$ & $168.18 \pm 4.74 \mathrm{a}$ & $150.23 \pm 6.65 \mathrm{~b}$ & $159.07 \pm 5.18 \mathrm{ab}$ \\
High of germinal epithelial cells of tubules & $55.75 \pm 2.61 \mathrm{a}$ & $57.94 \pm 4.42 \mathrm{a}$ & $47.10 \pm 2.50 \mathrm{~b}$ & $53.83 \pm 1.65 \mathrm{ab}$ \\
\hline
\end{tabular}

Values are represented as mean \pm SE. $n=8$. Different small letters denote the presence of significant differences $(P \leq 0.05)$ between periods. Control: rats received tap water; G1: received $10 \mathrm{mg} / \mathrm{kg}$ B.W. of CoQ10 orally; G2 received tap water contain NaF100 ppm and G3: received tap water contain NaF100 ppm Plus $10 \mathrm{mg} / \mathrm{kg}$ B.W. of CoQ10. 
Histological examination results also supported the above findings. No histological changes were observed in control group (Figure 1). After 55 days, a considerable histological change characterized with sever testicular amyloidosis represented by peritubular and sub capsular accumulation of homogeneous, eosinophilic and amorphous material in the interstitial of testicular lobules and within seminiferous tubules associated with disarranged of seminiferous tubules and depletion (Figure 2) were showed in the sections of testes of rats treated with Naf alone in drinking water. Besides, the magnified sections revealed marked microvacuolation occurred in the basal level of germ cells, amyloid deposited within seminiferous tubules with disarrangement and depletion of germ cells (Figure 3).

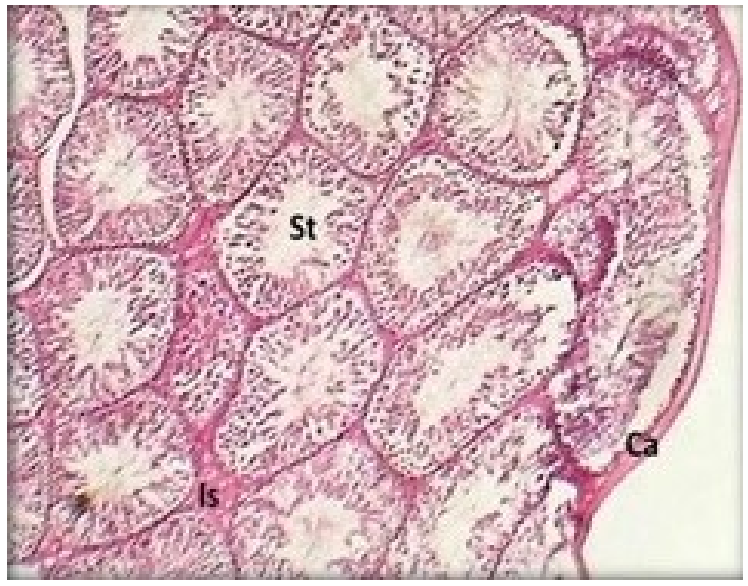

Figure 1: section of testis (control) shows testicular capsule (Ca). seminiferous tubules (St) and interstitium (Is). H\& E stain $40 \mathrm{X}$.

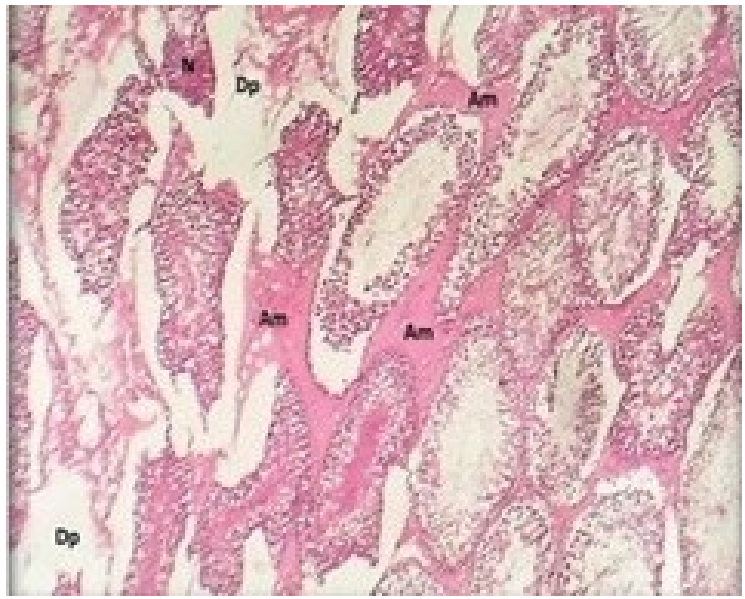

Figure 2: section of testis $\mathrm{G} 2$ group received $\mathrm{NaF}$ shows normal peritubular amyloidosis $(\mathrm{Am})$, tubular necrosis $(\mathrm{N})$, depletion (Dp) H\& E stain 40X.

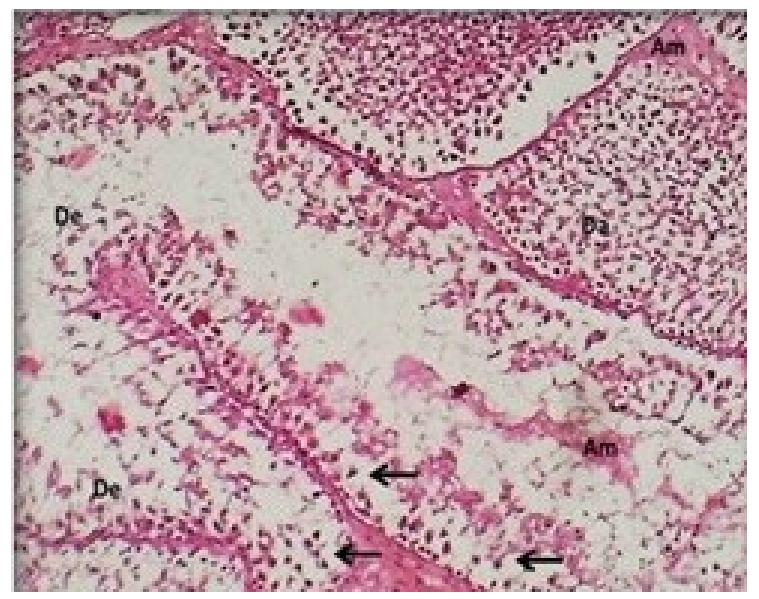

Figure 3: magnified section of seminiferous tubules group one $(\mathrm{NaF})$ shows: peritubular amyloidosis $(\mathrm{Am})$, depletion of germ cells(Dp) and microvaculation (arrows) H\& E stain $40 \mathrm{X}$.

Histological examination revealed sever degeneration and necrosis of germ cells (Figure 4) group of seminiferous tubules of group G1 as compared to control group. The testes of rats in groups G3 showed improved histological architecture and orderly arrangement of germinal cells compared to group G2with normal cytoarchitecture of spermatogenesis and few sections showed mild microvacuolation of germ cells (Figure 5). Also, the sections showed mild peritubular amyloidosis (Figure 6). It indicates the effective of CoQ10 in reducing the deleterious effects of $\mathrm{NaF}$ in tissue induced by $\mathrm{NaF}$. Whereas, CoQ10 (group-1) offered more degree of protection in histological findings (Figure 6).

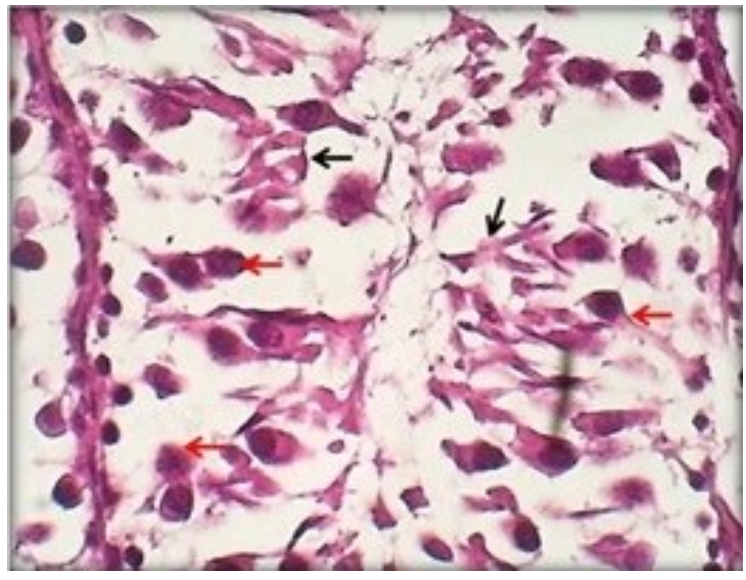

Figure 4: magnified section of seminiferous tubules group tow $(\mathrm{NaF})$ shows: degenerated germ cells (red arrows) and necrotic germ cells (black arrows) H\& E stain 40X. 


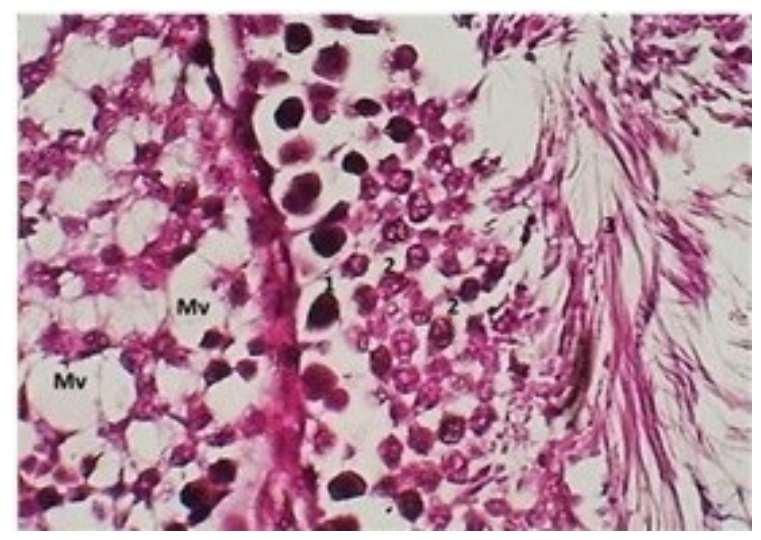

Figure 5: magnified section of seminiferous $(\mathrm{NaF}+\mathrm{coQ} 10)$ G3 shows: spermatogonium cells (1) primary and secondary spermatocytes (2) spermatids (3) and microvaculation (Mv) H \& E stain 40X.

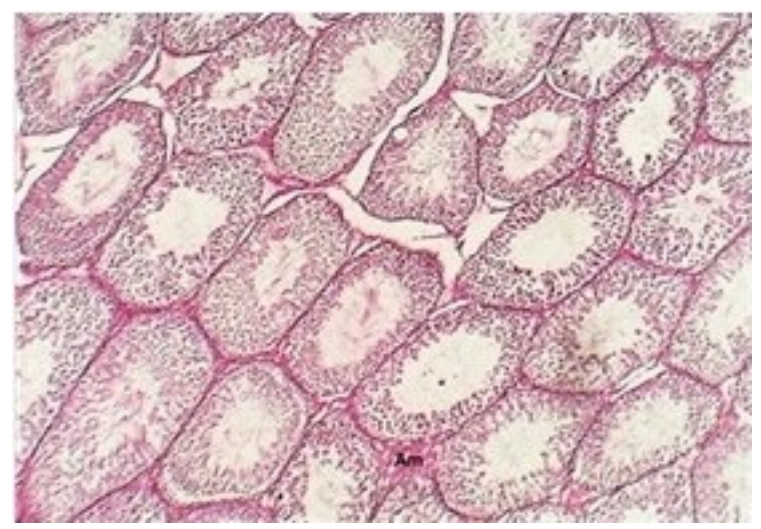

Figure 6: Section of testis group ons $(\mathrm{NaF}+\mathrm{Q} 10)$ shows: peritubular amyloidosis (Am) $\mathrm{H} \& \mathrm{E}$ stain $40 \mathrm{X}$.

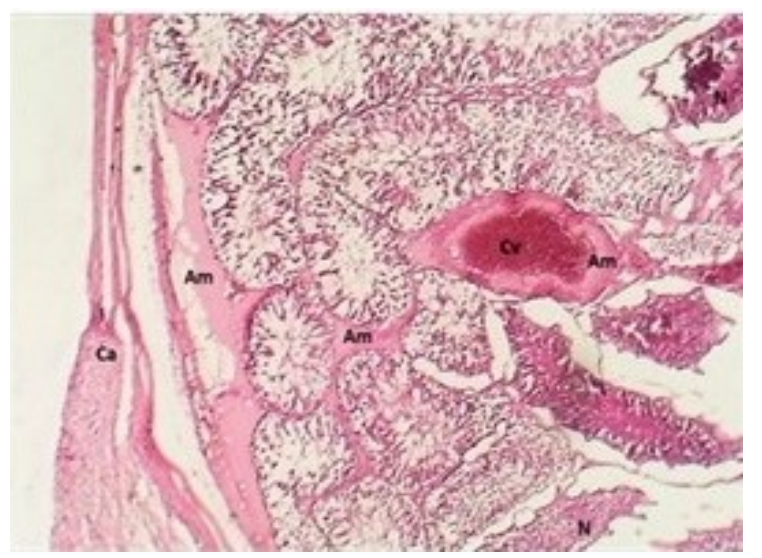

Figure 7: section of testis shows: peritubular and sub capsular amyloidosis (Am) \& perivascular amyloidosis (Cv-Am) and tubular necrosis $\mathrm{H} \& \mathrm{E}$ stain 40X.

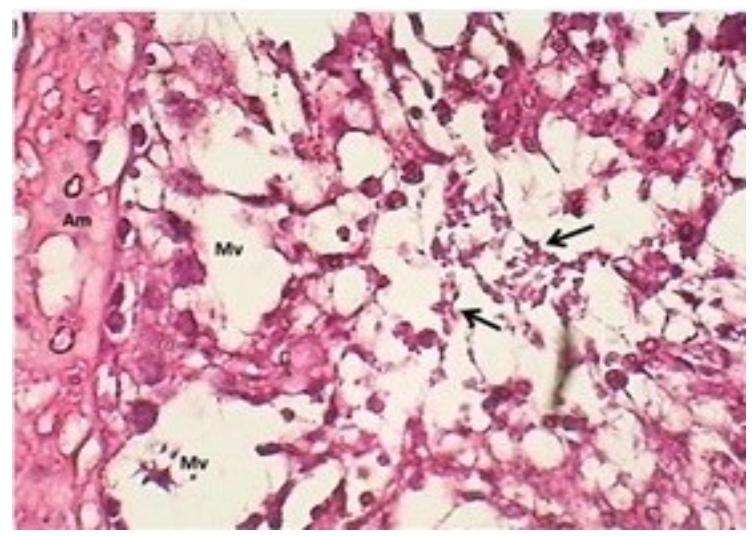

Figure 8: section of seminiferous tubule (CQ) shows: macrovaculation $(\mathrm{Mv})$, amyloidosis $(\mathrm{Am})$ and necrosis of germ cells $(\mathrm{N}) \mathrm{H} \& \mathrm{E}$ stain $40 \mathrm{X}$.

\section{Discussion}

The adverse effects of $\mathrm{NaF}$ and their amelioration by CoQ1O of testicular dysfunction in male rats have been observed in this experiment. The results revealed that rats received 100ppm of sodium fluoride (group $\mathrm{G}_{1}$ ) caused significant decrement in testosterone and LH concentrations as compared to other groups.

Testicular tissue characterized by an intense synthesis and secretion of testosterone, FSH and LH, as well as other biochemical activity related to spermatogenesis and sterdoigenesis (31). In agreement with previous studies, fluoride reduces testosterone levels by reducing the testicular zinc levels, which impairs angiotensin-converting enzyme (ACE) activity and hence causes inhibition of spermatogenesis, also, fluoride may inhibit androgen receptor mRNA expression in Sertoli cells resulted in a decrease in androgen receptor through which testosterone acts (32) or it caused a significant decreased of epidermal growth factor (EGF) and its receptor (EGFR) in Leydig's cells, spermatogonia and spermatocytes, which ultimately plays an important role in male reproductive functions of rat (33). LH is a glycoprotein. it is capable for synthesis and regulating the testosterone hormones secretion by Leydig cells (34). Seemingly, external elements and substances can impact the production and release of LH in the body, as in male subjects live in the epidemic fluorosis region, $\mathrm{LH}$ is much higher than that of the control region (35).

Sodium fluoride caused, inhibiting of some enzyme activity, that interrupting the metabolic processes such as glycolysis, synthesis of proteins, and antioxidative pathways. These changes, along with reduced food intake, causeda reduction in the body weight and thereby led to loss of testis weights $(36,37)$. Any alteration in androgen level may also result in changes in the weight of reproductive organs (35). As well as, $\mathrm{NaF}$ may be affected 
pituitary gland causing a reduction in the level of $\mathrm{GnRH}$, FSH and LH leading to inhibition or decrease of steroid biosynthesis (36). So, a decrease of testosterone concentration in NaF treated group (G1) was documented in the present study by induce histological alteration of the testis, which revealed loss of spermatogenesis, vacuolization and disorganization of germ cells and Leydig's cells (37). It has been reported that small amounts of reactive oxygen species (ROS) are produced in the steroidogenic pathway and spermatozoa are necessary for fertilizing capabilities. The findings of the present study support that oxidative stress-induced by Naf may be implicated in the pathogenesis of testicular dysfunctions and/or infertility as indicated by, histopathological alteration. Recently, (38) showed that oxidative stress plays a possible role in the apoptosis of Sertoli cells induced by $\mathrm{NaF}$, and that these effects can be suppressed with vitamin C.

The results of the present study showed a significant elevation in serum testosterone and $\mathrm{LH}$ concentration in Naf plus CoQ10 (G3) or CoQ10 alone (G1) groups as compared to group $\mathrm{G}_{1}$, may be refer to the antioxidant effects of CoQ10, which is able to reduce the negative effects of $\mathrm{NaF}$ on testicular function. Previous researches reported that antioxidants suppress the generation of reactive oxygen species by different mechanisms including, blunting the oxide and hydrogen peroxide, scavenges lipid peroxidation products during free radical, suppresses excess NO production It is well known that CoQ10 is an antioxidant molecule play an important role in the respiratory chain to produce energy as ATP. It has been showed that supplementation of CoQ10 supplement to infertile men can improve seminal parameters (39) and ameliorate tissue testicular damage leading to increase the levels of serum testosterone and luteinizing hormones level in cadmium exposed rabbits may be via its antioxidant activities (40), alsoCoQ10 might inhibit oxidative stress in rats-induced by Diethylstilbesterol (DES), one of endocrine-disrupting -chemicals (EDCs) $(41,42)$. Thereby, the reduced form of CoQ10-ubiquinol, acts as an antioxidant and preventing lipid peroxidation in biological membranes (42). Both the bioenergetics and the antioxidant role of CoQ10 suggest a possible involvement in sperm biochemistry and male infertility. The deep involvement of CoQ10 in male fertility may play a positive role in the treatment of asthenozoospermia, possibly related to not only to its function in the mitochondrial respiratory chain, but also to its antioxidant properties (23). Thus, it could be concluded that testicular dysfunction in sodium fluoride treated rats can be alleviated by CoQ10 may be due to its protection activity against damage by increasing antioxidant defense mechanism and thereby improving the testicular function.

\section{Reference}

1. Ashkani-Esfahani S, Bagheri F, Emami Y, Esmaeilzadeh E, Azarpira N, Hassanabadi N, Keshtkar M, Farjam M, Koohi-Hosseinabadi O, Noorafshan A. Protective effects of co-enzyme Q10 on thioacetamideinduced acute liver damage and its correlation with behavioral, biochemical, and pathological factors. Iran Red Crescent Med J. 2016;18(8):e29166.

2. Ben-meir A, Burstein E, Borrego-Alvarez A, Chong J, Wong E, Yavorska T, Naranian T, Chi M, Wang Y, Bentov Y. Coenzyme Q10 restores oocyte mitochondrial function and fertility during reproductive aging cell. 2015;14:887-895.

3. Chinoy NJ, Sequeira E. Effects of fluoride on the histoarchitecture of reproductive organs of the male mouse. Reprod Toxicol. 1989;3:2617.

4. Ekin S, Bayramogluo M. Cytoprotective effects of boric acid and coenzyme Q10 therapy on induced pulmonary fibrosis in response to intratracheal administration of bleomycin in rats. Fresen Environ Bull. 2013;22(8):2428-2434.

5. Abdel-Wahab WM. Protective effect of thymoquinone on sodium fluoride- induced hepatotoxicity and oxidative stress in rats. Jf Basi Appl Zool. 2013;66:263-270.

6. Littarru GP, Tiano L. Clinical aspects of coenzyme Q10:an update review. Nutrition. 2011;26(3):250-4.

7. Linnane AW, Kopsidas G, Zhang C, Yarovaya N, Kovalenko S, Papakostopoulos P, Eastwood H, Graves S, Richardson M. Cellular redoxactivity of coenzyme Q10: Effect of CoQ10 supplementation on human skeletal muscle. Free Radic Res. 2002;36(4):445-453.

8. Huang C, Yang H, Niu R, Sun Z, Wang J. Effect of sodium fluoride on androgen receptor expression in male mice. Fluoride. 2008;41:107.

9. Kawamukai M. Biosynthesis of coenzyme Q in Eukaryotes. Biosci Biotechnol Biochem, 2015;80:23-33.

10. Kumar A, Tripathi N, Tripathi M. Fluoride-induced biochemical changes in fresh water catfish (Clariasbatrachus, Linn). Fluoride. 2007;40(1):37-41.

11. Minamiyyama Y, Chikawa H, Masul T, Kobayashi K, Takemura S, Oka M, Yoshikawa T, Yamamoto Y. 228-Oral administration of reduced coenzyme Q10ameliorates the endocrine-disrupting chemicalinduced sperm toxicity in rats. Free Radic Biol Med. 2016;100:105106.

12. Mirmalek SA, Boushehrinejad AG, Yavari H, Kardeh B, Parsa Y, Salimi-Tabatabaee SA, Yadollah-Damavandi S, Parsa T, Shahverdi E, Jangholi E. Antioxidant and anti-inflammatory effects of coenzyme Q10 on L-arginine-induced acute pancreatitis in rat. Oxid Med Cell Longev. 2016;5818479.

13. Gvozdjáková A, Jarmila K, Jozef D, Viliam M, Ram B. Coenzyme Q10, $\alpha$-Tocopherol, and oxidative stress could be important metabolic biomarkers of male infertility. Dis Markers. 2015;15:1-6.

14. Balercia G, Mancini A, Paggil F, Tiano A, Pontecorvi M, Boscaro A, Lenzi G, Littarru P. Coenzyme Q10 and male infertility. J Endocrinol Invest. 2009;32(7):626-632.

15. López-Lluch G, Rodríguez-Aguilera JC, Santos-Ocaǹa C, Navas P. Is conenzyme Q a key factor in aging? Mech Ageing Dev. 2016;131:225-235.

16. Lafuente R, Gonzalez-Comadran M, Sola I, Lopez G, Brasseco M, Carreras R, Checa MA. Coenzyme Q10 and male infertility: A metaanalysis. J Assist Reprod Genet. 2013;30(9):1147-1156.

17. Butler MG, Dasouki M, Bittel D, Hunter S, Naini A, DiMauro S. Coenzyme Q10 levels in Prader-Willisyndrome: Comparison with obese and non-obese subjects. Am J Med Genet. 2003;119(2):168171.

18. Fatima S, Al-Mohaimeed N, Al-Shaikh Y, Tyagi P, Banu N, Hasan S, Arjumand S. Combined treatment of epigallocatechingallate and coenzyme Q10 attenuates cisplatin-induced nephrotoxicity via suppression of oxidative/nitrosative stress, inflammation and cellular damage. Food Chem Toxicol. 2016;94:213-220. 
19. Anjum KM, Mughal MS, Sayyed U, Yaqub A, Khalique A, Rashid MA, Yousaf MZ, Mumtaz MZ. Influence of increasing fluoride dose rates on selected liver and kidney enzymes profile in domestic chicken (Gallus domesticus). J Animal Plant Sci. 2014;24(1):77-80.

20. Banu SA, Asadulla S, Subbaiah MV. Coenzyme Q10: A Review of Its Promise. IOSR J Pharm Biol Sci. 2016;11(3):14-19.

21. Littarru GP, Tiano L. Bioenergetic and antioxidant properties of coenzyme Q10: recent developments. Mol Biol Technol, 2007;37(1):31-7.

22. Nadjarzadeh A, Shidfar F, Amirjannati N, Vafa MR, Motevalian SA, Gohari MR, NazeriKakhki SA, Akhondi MM and Sadeghi MR. Effect of Coenzyme Q10 supplementation on antioxidant enzymes activity and oxidative stress of seminal plasma: a double-blind randomized clinical trial. Andrologia. 2014;46,177-183.

23. Kumar A, Tripathi N, Tripathi M. Fluoride-induced biochemical changes in fresh water catfish (Clariasbatrachus, Linn). Fluoride. 2007;40(1):37-41.

24. Jianha Z, Ma J, Laing C Wang J. Effects of sodium fluoride and sulfur dioxide on oxidative stress and antioxidant defenses in rat testes. Fluoride, 2006;39(3):185-190.

25. Ali, S.A. Faddah, L.; Abdel-Baky, A. and Bayoumi, A. (2010). Protective effect of L-Carnitine and coenzyme Q10 on CCl4-induced liver injury in rats. Sci Pharm., 78(4): 881-896.

26. Ekin, S. and Bayramogluo, M. (2013). Cytoprotective effects of boric acid and coenzyme Q10 therapy on induced pulmonary fibrosis in response to intratracheal administration of bleomycin in rats. Fresen Environ Bull ., 22(8): 2428-2434.

27. Kawamukai M. Biosynthesis of coenzyme, eukaryotes. Biosci Biotechnol Biochem. 2015;80:23-33.

28. Para S, Raveendran R, Kesavan R. Blood sample collection in small laboratory animals. J Pharmacol Pharm therap. 2010;1(12):87-93.

29. Luna LG. Manual of Histology Staining. Methods of Armed Forces. Institute of Pathology. $3^{\text {rd }}$ edition. New York: McGraw-Hill Book Company; 1968.

30. Snedecor GW, Cochran W. Statistical Methods. $6^{\text {th }}$ ed. Iowa: The Iowa State University Press; 1973. 238-248 p.
31. Mueller WH. Fluoride compounds, inorganic, sodium: An encyclopedia of chemical Technology. London: John Wiley and Sons Inc; 2001.

32. Ganong WF. Review of medical physiology. $28^{\text {th }}$ edition. Toronto: Lange Medical Books; 2011:428.

33. Huang C, Yang H, Niu R, Sun Z, Wang J. Effect of sodium fluoride on androgen receptor expression in male mice. Fluoride. 2008;41:107.

34. Wan S, Zhang J, Wang J. Fluoride-induced changes in the expression of epidermal growth factor and its receptor in testicular tissues of young male rats. Fluoride. 2006;39:121-125.

35. Sofikitis N, Giotitsas N, Tsounapi P, Baltogianni, D, Pardalidis N. Hormonal regulation of spermatogenesis and spermiogenesis. $\mathrm{J}$ Steroid Biochem Mol Biol. 2008;109:323-330.

36. Pengfei MA, Xuemin BA, Yue ZHU, Jingyuan CUI. Effect of fluoride on human hypothalamic - Hypophysis-Tes9s axis hormones. J Environ Health. 2009;26(4):838-840.

37. Littarru GP, Tiano L. Bioenergetic and antioxidant properties of coenzyme Q10: Recent developments. Mol Biotechnol, 2007;37(1):31-7.

38. Zhou YS, Holmseth C, Guo B, Hassel G, Hofner HS, Huitfeldt KT, Wanner A, Danbolt, NC. Deletion of the GABA transporter 2 (GAT2, SLC6A13) gene in mice leads to changes in liver and brain taurine contents. J Biol Chem. 2012;287:35733-35746.

39. Messer HH, Armstrong WD, Singer L. Fertility impairment in mice on a low fluoride intake. Science. 1972;177:893-4.

40. Mohammed IA, Al-Okaily BN. Effect of sodium fluoride on liver functions of rats and amelioration by CoQ10. J Entomol Zoolo Studies. 2017;5(5):889-893.

41. Shults CW, Oakes D, Kieburtz K, Beal MF, Haas R, Plumb S, Juncos JL, Nutt J, Shoulson I, Carter J. Effects of coenzyme Q10 in early the functional decline. Arch Neurol. 2002;59(10):1541-1550.

42. Mueller WH. Fluoride compounds, inorganic, sodium: An encyclopedia of chemical technology. New York: John Wiley and Sons; 2011. 